\title{
PENATALAKSANAAN MIGREN PADA ANAK
}

\author{
Tri Makmur \\ Departemen Ilmu Penyakit Saraf \\ Fakultas Kedokteran, Universitas Islam Sumatera Utara \\ Medan, Indonesia \\ eMail: tri.makmur@yahoo.com
}

\begin{abstract}
Headache is the biggest part of human suffering that is often found not only in adults, but also in children. The prevalence of migraines in adult men is $9 \%$ and women are 18\%, while in children aged 7 years the prevalence is $1.2-3.2 \%$, and between the ages of $7-15$ years ranges between 4$11 \%$. Migraine attacks can be precipitated by certain foods that contain thyramin such as cheese, meat (hogdog and bacon), chocolate containing phenylthylamine, additives in foods such as monosodium glutamate. Many theories have been proposed, one of which is the vascular theory of migraine pathophysiology which describes that the occurrence of migraine attacks includes 2 phases. Migraine diagnosis is based on history, clinical observation and does not require diagnostic tests. In diagnosing migraine in children, diagnostic criteria are generally used. Migraine treatment is symptomatic. Patients and their families are informed about factors that can trigger migraine attacks and that attacks can be reduced through regular living and avoiding triggers. Generally migraine attacks must be treated if the frequency of attacks is frequent and sufficient to influence the child's activity. Short-term prognosis in children with migraines is more than $50 \%$ of patients report improvement within 6 months after treatment, while the long-term prognosis gets 2/3 of children will experience remission within 2 years or more.
\end{abstract}

Kata kunci: Migraine, Child

\section{PENDAHUlUAN}

Nyeri kepala merupakan bagian terbesar dari penderitaan manusia yang sering dijumpai bukan hanya pada orang dewasa, tetapi juga pada anakanak. Diperkirakan $70 \%$ dari seluruh anak-anak pernah menderita nyeri kepala minimal satu kali dan 20\% anak-anak usia 15 tahun pernah mengalami nyeri kepala berulang. Penyebab paling sering dari nyeri kepala berulang pada anak-anak adalah migren, yang biasanya mengenai 1 dari 9 anak usia 5-15 tahun dengan prevalensi antara 3.2$10.6 \%$ dan berdampak terhadap kehadiran si anak di sekolah dan kehadiran serta produktivitas kerja orang tua. Hampir $50 \%$ anak menderita migren tanpa aura dan kebanyakan mempunyai riwayat keluarga menderita migren. Migren terjadi pada 60-
$70 \%$ anak yang orangtuanya menderita migren. Serangan migren pada anak selalu dipicu oleh kelelahan, rasa cemas, sakit, kurang tidur, makanan yang mengandung tiramin, dan trauma kepala.

Migren berasal dari bahasa Yunani "Hemicrania", diperkenalkan pertama kali oleh Galen pada sekitar tahun 200 untuk mendeskripsikan suatu gangguan periodik yang terdiri dari nyeri kepala paroksismal, muntah, photophobia, nyeri kepala bersifat kumatkumatan dengan interval yang teratur dan berkurang dengan tidur dan berada di ruangan gelap.

Migren termasuk nyeri kepala vaskuler ditandai sebagai serangan yang terdiri dari kombinasi nyeri kepala dan kelainan neurologik, gastrointestinal dan gangguan otonomik. Serangan awal migren terjadi 
pada permulaan kehidupan; dimana $25 \%$ pada dekade pertama, 55\% pada usia 20 tahun dan lebih dari $90 \%$ pada usia di bawah 40 tahun. Serangan migren dapat dikurangi melalui hidup teratur dan menghindari faktor pencetus.

\section{DEFINISI}

Menurut World Federation of Neurology, migren adalah suatu kelainan yang bersifat familial dengan adanya serangan nyeri kepala yang berulang dengan intensitas, frekuensi dan lama yang bervariasi. Pada umumnya serangan migren bersifat unilateral, berdenyut, disertai hilangnya nafsu makan, mual, muntah dan membaik setelah tidur. Pada beberapa kasus dapat disertai gangguan emosi dan neurologis.

Migren dapat mengenai dewasa dan anak-anak. Prevalensi migren pada pria dewasa $9 \%$ dan wanita $18 \%$ dengan puncaknya pada usia 25-55 tahun yaitu usia produktif sehingga menyebabkan kehilangan waktu kerja, sedangkan pada anak usia 7 tahun prevalensinya adalah $1,2-3,2 \%$, dan pada usia 7-15 tahun berkisar antara 4-11\%. Sebelum pubertas prevalensi lebih tinggi pada pria dibanding wanita, namun setelah pubertas prevalensi meningkat pada wanita.

\section{FAKTOR PRESIPITASI}

Serangan migren dapat dipresipitasi oleh makanan tertentu yang mengandung thyramin seperti keju, daging (hogdog dan bacon), coklat yang mengandung phenylthylamine, zat tambahan pada makanan seperti monosodium glutamat. Selain itu serangan migren dapat dicetuskan oleh keadaan emosi, cemas, kelelahan, latihan, sakit, aktivitas fisik rutin, menstruasi, puasa, kurang tidur, perubahan cuaca, cahay terang, stress, ketegangan fisik mental dan trauma kapitis.

\section{PATOFISIOLOGI}

Patogenesis migren masih berkembang. Banyak teori yang telah diajukan, salah satunya adalah teori vaskular patofisiologi migren yang menggambarkan bahwa terjadinya serangan migren meliputi 2 phase yaitu:
Fase prodromal yang ditandai oleh vasospasme yang menyebabkan berkurangnya aliran darah serebral yang dimulai dari bagian otak oksipital dan menyebar ke depan, diikuti dengan timbulnya gejala neurologik fokal yang mengawali serangan. Fase kedua ditandai dengan adanya vasodilatasi ekstrakranial dan intrakranial yang menyebabkan meningkatnya aliran darah ke bagian korteks (daerah yang berhubungan dengan pendengaran, penglihatan) dan batang otak (nucleus raphe dorsal serotonergic dan nucleus cereleus adrenergik). Fase ini bertanggungjawab atas terjadinya nyeri kepala berdenyut yang biasanya dirasakan pada daerah yang mendapat persarafan nervus trigeminus dan radiks servikalis atas.

Banyak faktor yang dapat menginduksi distensi vaskular baik yang bersifat eksogen maupun endogen, antara lain: predisposisi genetik, stress, faktor makanan, pelepasan peptida vasoaktif dari sistem trigeminovaskular. Faktor ini bereaksi melalui korteks serebral, talamus dan hipotalamus menyebabkan perubahan fungsi otak.

Patogenesis migren klasik diterangkan teori vaskular dan teori neuronal. Terjadinya migren klasik didahului oleh gejala fokal yang berkaitan dengan depolarisasi paroksismal dari neuron korteks yang dinamakan aura. Timbulnya aura bersamaan dengan berkurangnya aliran darah serebral regional akibat vasokonstriksi serebral yang dimulai dari bagian oksipital menjalar ke depan sebagai suatu gelombang inhibisi aktivitas neuron yang menjalar sepanjang korteks dengan kecepatan lambat (2-3 mm/menit). Fenomena ini disebut "spreading depression". Hal ini berlangsung beberapa jam, kemudian diikuti dengan proses hiperemia dimana pada daerah yang mengalami penurunan aliran darah terjadi vasodilatasi reaktif dan peningkatan aliran darah serebral sehingga daerah tersebut mengalami hiperemia. Vasodilatasi terjadi pada arteri ekstrakranial yang menyebabkan aktivasi dan depolarisasi serabut saraf dari ganglion trigeminus sehingga terjadi pelepasan sejumlah substansia vasoaktif seperti peptida intestinal, substansi $P$, peptida terkait-gen kalsitonin yang menyebabkan terjadinya inflamasi sistem saraf yang berperan dalam timbulnya nyeri kepala. 
Pada saat serangan migren menjelang fase nyeri kepala, kadar serotonin platelet meninggi dan serotonin akan dilepas dari platelet dikarenakan adanya faktor pelepas-serotonin di dalam darah pada saat serangan dan akan menurun pada saat fase nyeri kepala. Dengan demikian ekskresi serotonin meningkat dalam urin sesudah serangan migren. Sesudah serotonin dilepas dari platelet serotonin tersebut mempunyai efek vasokonstriktor dan berperan pada dinding pembuluh darah terhadap rasa nyeri pada saat dilatasi. Ada dua jenis reseptor serotonin yang berperan pada nyeri kepala yaitu $5 \mathrm{HTI}$ yang berperan menghentikan serangan akut dan $5 \mathrm{HT} 2$ yang berperan mencegah timbulnya nyeri kepala.

Gambaran KlinisMigren Klasik (Migren Dengan Aura)

Migren klasik lebih jarang ditemukan pada anak dan remaja. Migren didahului oleh tanda-tanda neurologik aura. Aura yang paling sering adalah kelainan visual berupa bercak cahaya, garis-garis berwarna, penglihatan kabur, halusinasi visual dan sebagainya yang bersifat stereotipik dan dapat ditentukan pada satu mata.

Migren klasik merupakan suatu proses dua fase. Pada fase pertama (fase awal) terjadi gelombang eksitasi yang diikuti depresi fungsi kortikal yang menyebar pada kedua belahan otak dari belakang ke depan. Keadaan ini disertai dengan berkurangnya peredaran darah setempat yang menyebabkan depresi neuron. Pada fase kedua terjadi peningkatan aliran darah di arteri karotis interna dan eksterna sehingga menimbulkan nyeri kepala, mual dan muntah.

Serangan migren dapat berakhir pada fase awal tanpa nyeri kepala atau langsung ke fase kedua berupa nyeri kepala. Nyeri kepala mula-mula bersifat tumpul kemudian disusul rasa berdenyut terutama di daerah mata, dahi dan pelipis yang unilateral. Nyeri berlangsung selama 2-6 jam dan disertai dengan mual, muntah, anoreksia dan photophobia. Si anak tampak kesakitan dan rasa nyeri berkurang jika tidur dan keadaan pulih setelah bangun tidur. Selain itu sering ditemukan gejala disestesia tungkai dan daerah perioralMigren Tanpa Aura
Nyeri kepala tanpa aura sering ditemukan pada anak dan remaja (70\%) dan sulit dibedakan dari nyeri kepala oleh sebab lain. Aura tidak spesifik dan bermanifestasi sebagai rasa lemah, pucat dan mudah tersinggung selama 30 menit sampai beberapa jam. Manifestasi klinis berupa nyeri kepala bilateral di daerah periorbital dan berdenyut. Keadaan ini sering disertai mual, nyeri perut dan muntah. Muntah berulang merupakan manifestasi satu-satunya pada anak prasekolah. Biasanya si anak sulit menggambarkan bentuk nyeri kepala secara tepat, si anak tampak sakit, ingin tidur dan tidak tahan terhadap cahaya terang atau suara keras.

\section{DIAGNOSA}

Diagnosa migren didasarkan pada anamnesis, observasi klinis dan tidak memerlukan uji diagnostik. Pemeriksaan neurologi biasanya normal. Dalam menegakkan diagnosa migren pada anak secara umum digunakan kriteria diagnostik: adanya serangan nyeri kepala berulang dengan interval bebas gejala disertai dengan sedikitnya 3 gejala berikut: Adanya aura, biasanya visual. Adanya gejala gastrointestinal terutama mual dan muntah, tetapi dapat juga anoreksia dan sakit perut. Nyeri kepala pada salah satu sisi kepala. Nyeri berdenyut. Nyeri berkurang dengan tidur. Adanya riwayat migren dalam keluarga. Serangan migren sering dipresipitasi faktor pencetus seperti faktor psikologis, klinis, makanan, bahan kimia dan menstruasi. Nyeri kepala disertai paling sedikit 1 gejala:

a) Mual, muntah atau keduanya

b) Photophobia dan phonophobia

c) Tidak dijumpai penyakit organik

Kriteria diagnostik migren dengan aura:

1. Paling sedikit mengalami 2 serangan yang memenuhi (kriteria 2).

2. Terdapat paling sedikit 3 gejala berikut:

- Terdapat 1 atau lebih gejala aura fokal cerebral, kortikal dan disfungsi brainstem atau keduanya. 
- Paling tidak salah satu gejala auranya berkembang secara gragual lebih dari 4 menit

- Tidak ada aura yang berlangsung lebih dari 60 menit. Lebih banyak jenis auranya lebih lama serangannya bertambah.

3. Nyeri kepala timbul sesudah aura dengan interval bebas-serangan kurang dari 60 menit (nyeri kepala bisa mulai terjadi sebelum ataupun bersamaan dengan aura).

4. Anamnesis, pemeriksaan fisik dan test diagnostik mengeksklusikan penyebab sekunder.

Pemeriksaan electroenchepalography (EEG) tidak efektif digunakan dalam mendeteksi penyebab migren. Gambaran EEG yang abnormal tidak selalu dijumpai pada anak yang mengalami serangan migren. EEG biasanya normal disela-sela serangan migren, tetapi dapat menunjukkan fokus gelombang lambat selama atau setelah serangan migren. Seringnya ditemukan gelombang paku positif di daerah sentral dianggap menunjukkan adanya hubungan antara migren dengan epilepsi.

\section{ANALISIS}

Pengobatan migren bersifat simtomatik. Pasien dan keluarganya diberi informasi tentang faktor yang dapat mencetuskan terjadinya serangan migren dan bahwa serangan dapat dikurangi melalui hidup teratur dan menghindari faktor pencetus. Umumnya serangan migren harus diobati jika frekuensi serangan sering dan cukup untuk mempengaruhi aktivitas anak. Jika nyeri kepala berlangsung lebih dari 4 jam dan bila pengobatan sederhana tidak meredakan nyeri kepala dalam waktu 2 jam maka orangtua dianjurkan untuk mencari pengobatan. Dalam pengobatan migren terdapat 2 jenis pendekatan.

\section{A. Pengobatan Serangan Akut atau Abortif}

Serangan migren akut dapat diatasi dengan tirah baring di ruang gelap dan pemberian analgesik seperti asetaminofen, aspirin, ibuprofen. Pada nyeri kepala ringan dapat diberikan analgesik, namun pada kasus moderat dan berat pemberian analgesik tunggal menjadi tidak efektif dan hanya sedikit membantu karena analgesik lama diabsorpsi di dalam lambung. Kombinasi aspirin, butalbital, fenasetin dan kafein memberikan hasil yang lebih efektif pada kebanyakan pasien karena penambahan barbiturat merangsang tidur yang bermanfaat meredakan migren. Obat yang sering digunakan pada pengobatan abortif adalah preparat ergot dan triptan. Obat ergotamin tartrat dan sumatriptan berfungsi merangsang $5 \mathrm{HT} 1$ dan jika 5HT1 dirangsang maka serangan migren akut dapat dihentikan. Pada kebanyakan pasien dengan migren yang sering timbul aura diberi obat pilihan ergotamin tartrat, suatu substansi pemblokir adrenergik yang bersifat anti-serotonin. Obat ini bekerja menginduksi dengan kuat vasokonstriksi arteri, diberikan secara oral di awal serangan dan biasanya dalam bentuk kafergot. Dosis pemberian pada anak usia 6-9 tahun adalah $0,1 \mathrm{mg} /$ dosis, pada anak usia 9-12 tahun 0,5 mg/dosis dan usia 12-16 tahun $0,75 \mathrm{mg} /$ dosis. Preparat ergot bersifat kontraindikasi pada pasien penderita hipertensi dan penyakit jantung. Penggunaan obat ini terbatas dimana pemberian lebih dari 2-3 hari akan menimbulkan efek samping berupa reaksi sakit kepala rebound. Dengan ditemukannya obat baru jenis triptan, maka derivat ergot jarang digunakan.

Sumatriptan adalah suatu agonis 5 hydroxytryptamine 1 like receptor yang merupakan suatu vasokonstriktor selektif pada arteri intrakranial basalis yang besar menyebabkan berkurangnya aliran darah serebral dan pelepasan neuropeptida, berfungsi mengurangi proses inflamasi perivaskuler dan menghambat transmisi nyeri melalui nervus trigeminus dan hubungannya ke pusat nyeri. Obat ini efektif baik pada migren dengan aura ataupun tanpa aura dan efektif pada serangan migren moderat dan berat dengan mual ringan, fotofobia dan fonofobia. Obat ini tersedia dalam beberapa bentuk seperti tablet oral $(25 \mathrm{mg}$, $50 \mathrm{mg}, 100 \mathrm{mg})$, subkutan $(6 \mathrm{mg})$, spray nasal (20 $\mathrm{mg}$ ), suppositoria (25 mg). Sumatriptan diberikan secara oral pada saat serangan nyeri kepala dan rata-rata $80 \%$ akan membaik dalam 2 jam setelah pemberian. Pada orang dewasa dengan dosis 100 $\mathrm{mg}$, memberikan hasil yang sangat baik. Pada anak 
obat ini cukup efektif dan aman dengan dosis 0,06 $\mathrm{mg} / \mathrm{kg}$.

\section{b. Pencegahan Serangan Migren}

Cukup banyak obat yang digolongkan ke dalam kelompok pencegah migren seperti siproheptadin, metisergid, antidepresan trisiklik, penghambat kanal kalsium, penghambat adrenoreseptor beta, antikonvulsan yang berfungsi sebagai antagonis atau mengatur turun $5 \mathrm{HT} 2$ yang membantu dalam mencegah timbulnya migren.

Siproheptadin, suatu histamin dan antagonis reseptor serotonin digunakan untuk profilaksis migren pada anak. Pemberian dosis 4-12 mg. Efek samping yang sering terjadi berupa rasa lelah dan sedasi, peningkatan berat badan.

Metisergid, suatu antagonis reseptor serotonin. Obat ini jarang digunakan pada saat ini karena menimbulkan risiko komplikasi berupa fibrosis peritoneal dan thromboflebitis.

Antidepresan termasuk modulator serotonin dan efektif dalam profilaksis migren. Obat ini lebih efektif daripada inhibitor penyerapan-kembali serotonin selektif. Pemilihan antidepresan didasarkan pada apakah penderita mengalami gangguan tidur. Pada yang tidak mengalami gangguan tidur lebih toleran terhadap antidepresan non-sedatif seperti desipramin dan protriptilin, sedangkan yang mengalami gangguan tidur lebih toleran terhadap antidepresan yang bersifat sedatif seperti amitriptilin dan imipramine. Dosis amitriptlin adalah 0,1-2 mg/kg.

Penghambat kanal kalsium seperti verapamil, nikardipin dan flunarizin digunakan dalam profilaksis migren, migren dengan ataupun tanpa aura. Flunarizin dengan dosis $5 \mathrm{mg} /$ hari digunakan untuk mencegah serangan migren pada anak baik dengan ataupun tanpa aura. Obat ini juga dapat digunakan pada serangan migren yang resistan terhadap propanolol. Efek samping yang sering ditemukan adalah sedasi, peningkatan berat badan, depresi dan konstipasi.

Penghambat adrenoreseptor beta merupakan obat yang paling efektif untuk profilaksis migren. Yang sering digunakan adalah propanolol dan timolol. Pada anak dengan berat badan $<35 \mathrm{~kg}$ dosis maksimum adalah $20 \mathrm{mg} 3 \times$ sehari sedangkan jika berat badan $>35 \mathrm{~kg}$ dosis adalah $40 \mathrm{mg} 3 \times$ sehari. Meskipun obat ini merupakan profilaksis yang baik, namun kebanyakan anak mengeluh susah tidur. Obat ini tidak boleh diberikan pada anak penderita asma, penyakit jantung dan diabetes.

Obat antikonvulsan natrium divalproex merupakan obat profilaksis yang efektif dalam pengobatan migren. Dosis pemberian adalah 250 $\mathrm{mg} /$ hari. Obat ini bekerja meningkatkan kadar inhibitor asam amino $y$ aminobutyric acid (GABA) dan mengurangi kadar asam amino glutamat pada sistem saraf pusat. Efek samping meliputi peningkatan berat badan, tremor, rambut rontok, keracunan hepar (jarang).

Selain dengan obat-obatan, serangan migren dapat dicegah dengan penanganan stress dan mengatur kondisi badan melalui pikiran (biofeedback), makan dan tidur secara teratur, mencegah/menghindari makanan yang dapat mencetuskan terjadinya migren (seperti susu lembu, telur, coklat, jeruk, daging, keju, asam benzoat, dan lain-lain) serta banyak berolahraga.

\section{PROGNOSIS}

Prognosis jangka pendek pada anak penderita migren adalah baik. Lebih dari $50 \%$ pasien melaporkan pembaikan dalam 6 bulan setelah pengobatan. Prognosis jangka panjang mendapatkan 2/3 anak-anak akan mengalami remisi dalam 2 tahun atau lebih. Angka remisi pada usia < 8 tahun adalah 22\% dan pada usia 8-14 tahun adalah $25 \%$. Remisi lebih sering pada wanita dibanding pria dengan ratio 3:2 dan prognosis lebih baik pada pria dibanding wanita.

\section{DAFTAR PUSTAKA}

[1] S. Lazuardi, Nyeri Kepala pada Anak dan Remaja. Buku Ajar Neurologi, 2nd ed., Jakarta: Ikatan Dokter Indonesia, 2000, pp.78-86.

[2] A. Pakalnis, "New avenues in treatment of paediatric migraine: a review of the literature," Famili Practice, vol. 18, no. 1, pp. 101-106, 2001.

[3] J. Gilroy, Basic Neurology, 3rd ed., New York: McGraw Hill Company, 2000, pp.127-135. 
[4] N. H. Ruskin, Migraine And Other Head Ache. Merrit's Neurology, 10th ed., Philadelphia: Lippincott William \& Wilkins, 2000, pp.807-813.

[5] P. R. Simon, M. J. Aminof, and D. A. Greenberg, Clinical Neurology, 4th ed., New York: Appleton \& Lange, 2000, pp.78-86.

[6] D. S. Silberstein, R. B. Lipton, and D. J. Dalessio, Wolf Headache and Other Head Pain, London: Oxford University Press, 2001, pp. 121200.
[7] E. L. H. Spierings, Migraine, 2nd ed., Boston: Merit Publishing International, 2002.

[8] J. H. Menkes, Textbook of Child Neurology, 5th ed., Baltimore: Williams \& Wilkins, 1995, pp. 791-799.

[9] H. Sjahrir, Nyeri Kepala dan Vertigo, Medan: Universitas Sumatera Utara Press, 1998, pp 4,38-58. 